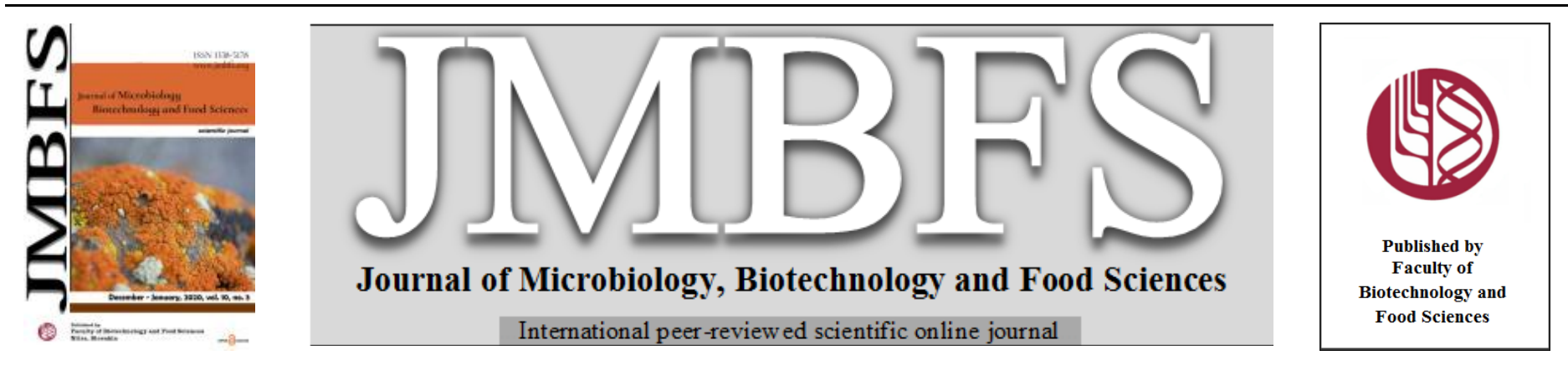

\title{
HETEROLOGOUS EXPRESSION OF A GENE ENCODING BIPHENYL 2,3-DIOXYGENASE FROM BURKHOLDERIA CEPACIA IN ESCHERICHIA COLI
}

\author{
Duong Duc Hoang Sinh ${ }^{l \#}$, Nguyen Hoang Tue ${ }^{l \#}$, Tran Vu Ngoc Thi ${ }^{l}$, Le Thi Ha Thanh ${ }^{l}$, Nguyen Duc Huy ${ }^{2}$, Nguyen Hoang Loc ${ }^{{ }^{*}}$
}

$\operatorname{Address(es):~}$

${ }^{1}$ Institute of Bioactive Compounds, University of Sciences, Hue University, 77 Nguyen Hue St., Hue, Thua Thien Hue 530000, Vietnam.

${ }^{2}$ Institute of Biotechnology, Hue University, Phu Vang, Thua Thien Hue 530000, Vietnam.

\#Duong Duc Hoang Sinh and Nguyen Hoang Tue contributed equally in this article

*Corresponding author: nhloc@ hueuni.edu.vn

doi: 10.15414/jmbfs.2020.10.3.490-492

ARTICLE INFO

Received 9. 5.2019

Revised 23. 9. 2020

Accepted 24. 9. 2020

Published 1. 12. 2020

Short communication

open $\odot$ access

\section{INTRODUCTION}

Biphenyl, one of four substrates of biphenyl 2,3-dioxygenase, is an aromatic hydrocarbon in which two benzene rings are connected to each other. Polychlorinated biphenyls have been widely used for various industrial purposes, these compounds are recognized to be some of the most serious environmental pollutants worldwide (Furukawa et al., 2004). Biphenyl 2,3-dioxygenase, also called biphenyl dioxygenase subunit alpha (BphA), is an enzyme that belongs to the family of oxidoreductase participating in initiatory step of the pathway of biphenyl degradation in bacteria (Leewis et al., 2016). Mondello (1989) and Seeger et al. (1995) had cloned and expressed genes encoding biphenyl dioxygenase of Pseudomonas strain LB400 in E. coli. The BphA genes of Rhodococcus globerulus P6 were also expressed in Pseudomonas putida by McKay et al. (1997). Recently, Ohmori et al. (2011) expressed the BphA genes from Rhodococcus jostii RHA1 in E. coli. In alternative way, Hu et al. (2014) activated the expression of BphAl gene in Pseudomonas fluorescence $\mathrm{P} 2 \mathrm{~W}$ and Ralstonia eutropha $\mathrm{H} 850$ by treatment of these bacteria with salicylic acid and biphenyl. In our knowledge, there is not any report on production of recombinant BphA enzyme from B. cepacia. Therefore, in the present study, we report some preliminary results on the expression of $B p h A$ gene from $B$. cepacia strains DF2 and DF4 in E. coli.

Two B. cepacia strains DF2 and DF4 (GenBank accession No: MG768914 and MG768915) were isolated from dioxin contaminated soil in former ASo air-base, A Luoi district, Thua Thien Hue province, Vietnam. Total DNA of bacteria was extracted using PowerSoil ${ }^{\mathbb{B}}$ DNA Isolation Kit (MO BIO, Qiagen). The 5'- and 3'- untranslation regions of the full-length biphenyl 2,3-dioxygenase gene from Burkholderia cenocepacia MSMB384WGS (CP013452.1) were used to design specific primers (forward: 5'-GGATCCATGATCGATG-TCCGTG-3' and reverse: 5'-AAGCTTCCGGTATCCGATGCTG-3') for PCR amplification of the coding DNA sequence (CDS) of BphA gene in B. cepacia DF2 and DF4. 5'GGATCC-3' and 5'-AAGCTT-3' are overhang ends for BamHI and HindIII, respectively. PCR components were as follows: $50 \mathrm{ng}$ total DNA, $10 \mathrm{pmol}$ each primer, $6 \mu \mathrm{L} 2 \times$ GoTaq $^{\circledR}$ Green Master Mix (Promega) in a volume of $12 \mu \mathrm{L}$. Amplification was performed in thermocycler Veriti (ABI) with thermal cycles: genomic denaturation at $95^{\circ} \mathrm{C}$ for $15 \mathrm{~min} ; 30$ cycles of $95^{\circ} \mathrm{C}$ for $30 \mathrm{sec}, 55^{\circ} \mathrm{C}$ for $1 \mathrm{~min}$ and $72^{\circ} \mathrm{C}$ for $1.5 \mathrm{~min}$; finally an extension of $72^{\circ} \mathrm{C}$ for $10 \mathrm{~min}$.

PCR product (CDS of putative BphA gene) after purification by GeneJET Gel Extraction Kit (Thermo Scientific) was inserted into pGEM ${ }^{\circledR}$-T-Easy vector (Promega) and was then transformed in E. coli TOP10 cells by the heat-shock method (Sambrook et al., 1987). Putative BphA gene was sequenced using the dideoxy chain-termination method on ABI 3130 system. Phylogenetic tree was constructed from the CDS alignment of BphA genes in bacterial species using MEGA7 software.

Recombinant pGEM ${ }^{\circledR}$ T-Easy/BphA vector was digested with BamHI and HindIII, and pQE30 expression vector (Qiagen) was also opened with the same enzymes. Digested products were purified with MEGA quick-spin ${ }^{\mathrm{TM}}$ Total Fragment DNA Purification Kit (iNtRON Biotechnology) which were then ligated together using T4 DNA ligase (Promega), and finally was introduced into E. coli M15. Transformed E. coli M15 was proliferated in $5 \mathrm{~mL}$ of liquid LB medium containing $50 \mu \mathrm{g} / \mathrm{mL}$ ampicillin at $37^{\circ} \mathrm{C}$ overnight with a shaking speed of 180 rpm. Then, $50 \mu \mathrm{L}$ of overnight culture was transferred into $50 \mathrm{~mL}$ of fresh $\mathrm{LB}$ medium and cultured in the same condition until OD at $600 \mathrm{~nm}$ reaches 0.5 , add $0.5 \mathrm{mM}$ isopropyl $\beta$-D-1-thiogalactopyranoside (IPTG) to the medium and culture for another $4 \mathrm{~h}$. Total soluble protein (TSP) content of cell was measured by the Bradford's method (1976), and $10 \mu \mathrm{g}$ of TSP was used for sodium dodecyl sulfate-12\% polyacrylamide gel electrophoresis (SDS-PAGE) to evaluate expression of BphA gene.

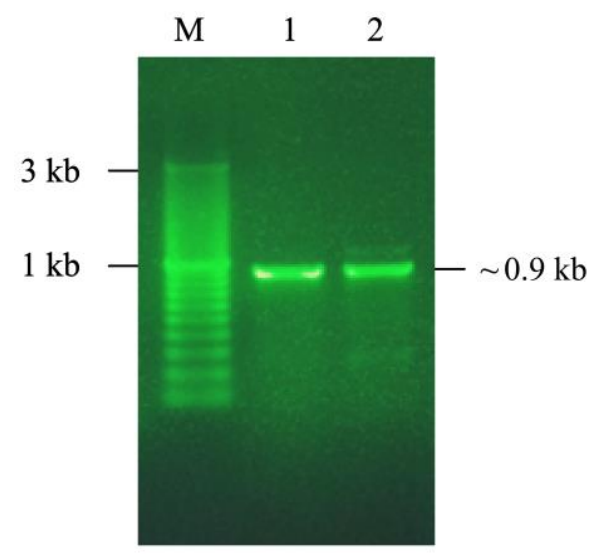

Figure 1 PCR amplification of putative BphA genes from Burkholderia cepacia strains DF2 and DF4. M: DNA size marker, 1: DF2 and 2: DF4. 
PCR amplification of putative BphA gene (CDS) from B. cepacia DF2 and DF4 with specific primers was showed in Figure 1. The amplicons have sizes as expected with approximately $0.9 \mathrm{~kb}$ in length. The nucleotide sequences of the amplicons are 99\% identical to a gene encoding biphenyl 2,3-dioxygenase of $B$. cepacia INT3-BP177 (AOI85724.1). Two sequences of BphA genes from DF2 and DF4 were deposited in GenBank with accession numbers of MF953295.1 and MF953300.1, respectively. Figure 2 shows the alignment of deduced amino acid sequences between three BphA genes from B. cepacia DF2, DF4 and INT3BP177. The identity levels of all proteins are also $99 \%$

\begin{tabular}{|c|c|c|c|}
\hline DF2 & 1 & MIDVRALGYVVVEATRVDAWRRYAEDVLGMQALDAPDGALYLKMDERDFRYVIVPGSTDF & \\
\hline DF4 & 1 & MIDVRALGYVVVETTRVDAWRRYAEDVLGMQALDAPDGALYLKMDERDFRYVIVPGSADF & \\
\hline INT3-BP177 & 1 & MIDVRALGYVVVEATRVDAWRRYAEDVLGMOALDAPDGALYLKMDERDFRYVIVPGSADF & \\
\hline F2 & 61 & YFASGWELPDGAAFDAALAVLQRAGVEPIRATPAEAV̄LRRVQAMAWCTDPSGNRHELYWG & \\
\hline F4 & 61 & YFASGWELPDGAAFDAALAVLQRAGVEPIRATPAEAALRRVQAMAWCTDPSGNRHELYWG & \\
\hline INT3-BP177 & 61 & YFASGWELPDGAAFDAALAVLQRAGVEPIRATPAEAALRRVQAMAWCTDPSGNRHELYWG & \\
\hline F2 & 121 & AHFVTGDMGLGHAVLPAPQFDATDAFVRGVLGFELSDIYRVKFTPD & \\
\hline DF4 & 121 & ARCDFRRFVSPLGVAHFVTGDMGLGHAVLPAPQFDATDAFVRGVLGFELSDIYRVKFTPD & \\
\hline INT3-BP177 & 121 & ARCDFRRFVSPLGVAHFVTGDMGLGHAVLPAPQFDATDAFVRGVLGFELSDIYRVKFTPD & \\
\hline F2 & 181 & JARHHSLALFEMAVPSGCVHVI & \\
\hline DF4 & 181 & 2NARHHSLALFEMAVPSGCVHVMAEVDSMDEVGRALDRVAAHDVKMS & \\
\hline INT3-BP177 & 181 & PAEPEKRIHFMHCRNARHHSLALFEMAVPSGCVHVMAEVDSMDEVGRALDRVAAHDVKMS & \\
\hline 28 & 241 & MKTPGGFDLEYGFGGLTVDh & \\
\hline F4 & 241 & YMKTPGGFDLEYGFGGLTVDW & \\
\hline [NT3-BP177 & 241 & ATLGRHCNDQMISFYMKTPGGFDLEYGFGGLTVDWSKHAVFEATKVSQWGHDFSIGYR & 29 \\
\hline
\end{tabular}

Figure 2 The alignment of deduced amino acid sequences from three BphA genes of Burkholderia cepacia strains DF2 (AXL14076.1), DF4 (AXL14081.1) and INT3BP177 (AOI85724.1). Black boxes are different amino acids.

The BphA genes from two strains B. cepacia DF2 and DF4 were subjected to phylogenetic analysis using MEGA7 software. The phylogenetic tree was created using Marximum Likelihood method (Tamura and Nei, 1993; Kumaret et al., 2015) with bootstrap support of 1000 replicates. The tree is drawn to scale, with branch lengths measured in the number of substitutions per site. From results are shown in Figure 3, it can be seen that corresponding genes cluster with very high bootstrap values. This proves that the BphA genes are highly preserved in Burkholderia genus. The tree helps show orthologs and paralogs of these genes in B. cepacia, B. cenocepacia and B. stabilis.

Expression of BphA genes from DF2 and DF4 in E. coli M15 was induced with IPTG. SDS-PAGE showed that BphA enzyme was produced in high content and they have molecular weight (MW) as expected (approximately $33 \mathrm{kDa}$ ) corresponding to deduced amino acid sequences (298 aa) (Fig 4).

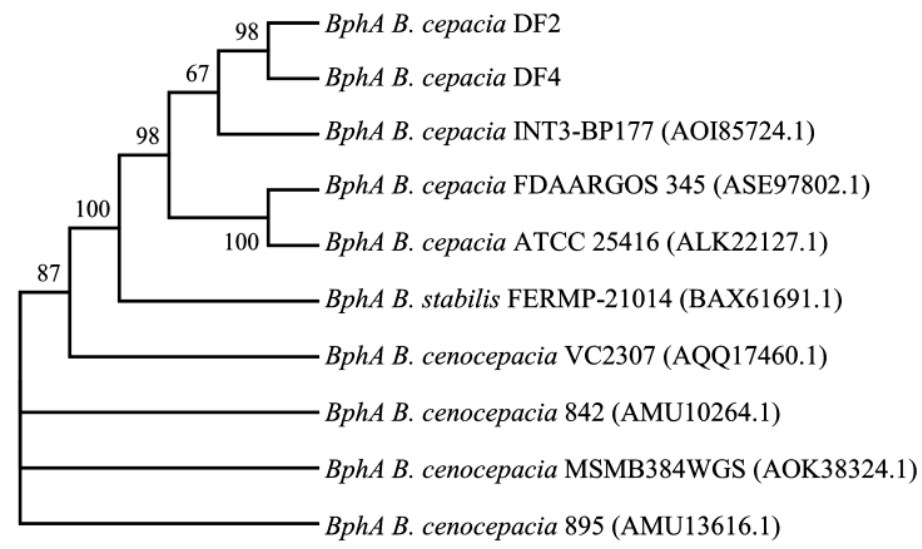

Figure 3 Molecular phylogenetic analysis of BphA genes encoding biphenyl 2,3dioxygenases from strains Burkholderia cepacia, Burkholderia cenocepacia and Burkholderia stabilis. The percentage of trees in which the associated taxa clustered together is shown next to the branches.

Several previous reports showed the BphA gene has been expressed in various host cells. For example, McKay et al. (1997) heterologously expressed biphenyl dioxygenase genes from $R$. globerulus P6 in P. putida cells. Ohmori et al. (2011) obtained BphAc enzyme (MW of $11.5 \mathrm{kDa}$ ) of $R$. jostii RHA1 from recombinant E. coli Rosetta (DE3) pLacI cells. According to Haddock and Gibson (1995), biphenyl 2,3-dioxygenase from Pseudomonas sp. LB400 is composed of a large (alpha) subunit (approx. $53.3 \mathrm{kDa}$ ) and small (beta) subunit (approx. 27.3 kDa). While biphenyl 2,3-dioxygenase alpha subunit from Cupriavidus sp. WS (G-44364, MetaCyc) has a molecular weight of $51.649 \mathrm{kDa}$ that estimated from the nucleotide sequence.

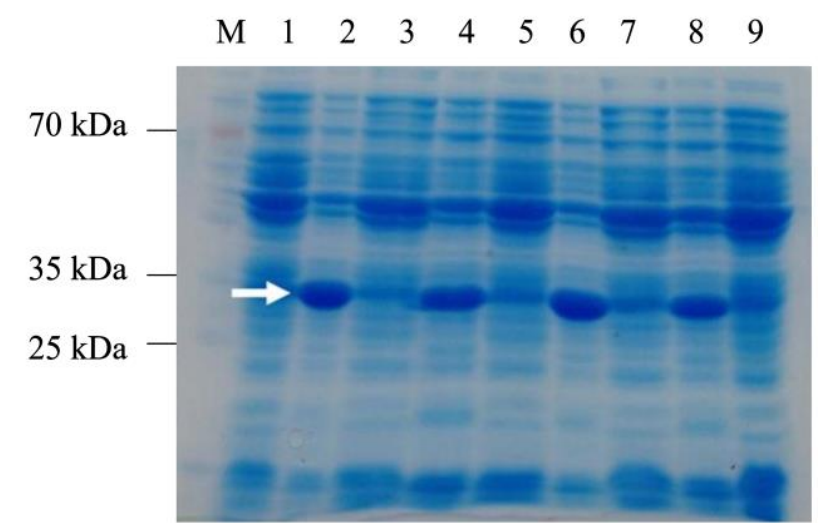

Figure 4 SDS-PAGE of total soluble protein from recombinant Escherichia coli M15 containing pEQ30/BphA vector. M: protein molecular weight marker. 1: non-transformed Escherichia coli M15. 2: BphA gene from DF2 was induced with IPTG. 3: BphA gene from DF2 was non-induced with IPTG. 4, 6 and 8 BphA gene from DF4 was induced with IPTG. 5, 7 and 9: BphA gene from DF4 was non-induced with IPTG. Arrow indicates bands of recombinant biphenyl 2,3dioxygenase in Escherichia coli M15.

Aknowledgments: This study was supported by Department of Science and Technology, Thua Thien Hue Province, Vietnam (Code: TTH.2016-KC.03). The authors would also like to thank Hue University, Vietnam for supporting this study.

\section{REFERENCES}

Bradford, M.M. (1976). A rapid and sensitive method for the quantitation of microgram quantities of protein utilizing the principle of protein-dye binding. $\begin{array}{lll}\text { Analytical } & \text { Biochemistry, } & \text { 72(1-2), }\end{array}$ https://doi.org/10.1006/abio.1976.9999.

Furukawa, K., Suenaga, H., \& Goto, M. (2004). Biphenyl dioxygenases: Functional versatilities and directed evolution. Journal of Bacteriology, 186(16), 5189-5196. https://doi.org/10.1128/JB.186.16.5189-5196.2004.

Haddock, J.D., \& Gibson, D.T. (1995). Purification and characterization of the oxygenase component of biphenyl 2,3-dioxygenase from Pseudomonas sp. strain LB400. Journal of Bacteriology, 177(20), 5834-5839. https://doi.org/10.1128/jb.177.20.5834-5839.1995.

Hu, C., Zhang, Y., Tang, X., \& Luo, W. (2014). PCB biodegradation and $b p h A 1$ gene expression induced by salicylic acid and biphenyl with Pseudomonas fluorescence $\mathrm{P} 2 \mathrm{~W}$ and Ralstonia eutropha H850. Polish Journal of Environmental Studied, 23(5), 1591-1598.

Kumar, S., Stecher, G., \& Tamura, K. (2015). MEGA7: Molecular evolutionary genetics analysis version 7.0. Molecular Biology and Evolution, 33(7): 1870- 
1874. https://doi.org/10.1093/molbev/msw054.

Leewis, M.C., Uhlik, O., \& Leigh, M.B. (2016). Synergistic processing of biphenyl and benzoate: Carbon flow through the bacterial community in polychlorinated-biphenyl-contaminated soil. Scientific Report, 6 , Article number: 22145. https://doi.org/10.1038/srep22145.

McKay, D.B., Seeger, M., Zielinski, M., Hofer, B., \& Timmis, K.N. (1997). Heterologous expression of biphenyl dioxygenase-encoding genes from a Grampositive broad-spectrum polychlorinated biphenyl degrader and characterization of chlorobiphenyl-oxidation by the gene products. Journal of Bacteriology, 179(6), 1924-1930. https://doi.org/10.1128/jb.179.6.1924-1930.1997.

Mondello, F.J. (1989). Cloning and expression in Escherichia coli of Pseudomonas strain LB400 genes encoding polychlorinated biphenyl degradation. Journal of Bacteriology, 171(3), 1725-1732. https://doi.org/10.1128/jb.171.3.1725-1732.1989.

Ohmori, T., Morita, H., Tanaka, M., Tomoi, M., Miyauchi, K., Kasai, D., Furukawa, K., Masai, E., \& Fukuda, M. (2011). Expression in Escherichia coli of biphenyl 2,3-dioxygenase genes from a Gram-positive polychlorinated biphenyl degrader, Rhodococcus jostii RHA1. Bioscience, Biotechnology and Biochemistry, 75(1), 26-33. https://doi.org/10.1271/bbb.100452.

Sambrook, J., Fritsch, E.F., \& Maniatis, T. (1987). Molecular cloning: a laboratory manual. $2^{\text {nd }}$ Ed. Cold Spring Harbor Laboratory Press, NewYork.

Seeger, M., Timmis, K.N., Hofer, B. (1995). Degradation of chlorobiphenyls catalyzed by the $b p h$-encoded biphenyl-2,3-dioxygenase and biphenyl-2,3dihydrodiol-2,3 dehydrogenase of Pseudomonas sp. LB400. FEMS Microbiology Letters, 133(3), 259-264. https://doi.org/10.1111/j.1574-6968.1995.tb07894.x.

Tamura, K., Nei, M. (1993). Estimation of the number of nucleotide substitutions in the control region of mitochondrial DNA in humans andchimpanzees.
Molecular
Biology
and
Evolution
10(3),
$512-526$.

https://doi.org/10.1093/oxfordjournals.molbev.a040023. 